Jurnal Agro 8(2), 2021

\title{
KULTUR SUSPENSI SEL TANAMAN GAJAH BERANAK (Goniothalamus tapis Miq) TERHADAP KANDUNGAN ZAT GONIOTALAMIN
}

\section{SUSPENSION CELL CULTURE OF GAJAH BERANAK (Goniothalamus tapis Miq) ON GONIOTHALAMINE COMPOUND CONTENT}

\author{
Imam Mahadi*, Sri Wulandari, Wan Safii, Irda Sayuti \\ Program Studi Pendidikan Biologi, FKIP, Universitas Riau \\ Jl. Bina widya, Simpang Baru, Kec. Tampan, Kota Pekanbaru, Riau 28292 \\ *Korespondensi: imam.mahadi@lecturer.unri.ac.id
}

Diterima : 08 November 2021 / Disetujui : 27 Desember 2021

\begin{abstract}
ABSTRAK
Zat goniotalamin pada tanaman gajah beranak (Goniothalamus tapis) merupakan obat alternatif penyembuhan kanker. Penelitian bertujuan untuk mendapatkan zat goniotalamin melalui kultur kalus dan kultur suspensi sel. Metode penelitian eksperimen Rancangan Acak Lengkap (RAL) dengan kombinasi 2,4-D (1-10 $\left.\mathrm{mg} \mathrm{L}^{-1}\right)$ dan BAP $\left(0,5-2 \mathrm{mg} \mathrm{L}^{-1}\right)$ menggunakan eksplan batang muda, terdiri dari 17 perlakuan dan 3 kali ulangan. Analisis data menggunakan Analysis of Variances dan uji lanjut Duncan Multiple Range Test (DMRT) taraf 5\%. Hasil menunjukkan bahwa kultur kalus $G$. tapis pada media 5,0 $\mathrm{mg} \mathrm{L}^{-1} 2,4-\mathrm{D}+1 \mathrm{mg} \mathrm{L}^{-1} \mathrm{BAP}$ adalah yang terbaik dengan waktu muncul kalus 28,33 hari dan persentase pembentukan kalus $100 \%$. Kalus untuk kultur suspensi sel bertekstur remah dan berwarna kuning kehijauan. Kultur suspensi sel menghasilkan pertumbuhan sel yang cepat, tidak lembek berair dan mudah dipisahkan. Hasil kualitatif Kromatografi Lapis Tipis kultur suspensi sel sangat jelas, bersih dan terdapat potensi kandungan zat goniotalamin pada perlakuan 2,4-D $5 \mathrm{mg} \mathrm{L}^{-1}+\mathrm{BAP} 0,5 \mathrm{mg} \mathrm{L}^{-1}$, 2,4-D $5 \mathrm{mg} \mathrm{L}^{-1}+$ BAP $1 \mathrm{mg} \mathrm{L}^{-1}$, 2,4-D $5 \mathrm{mg} \mathrm{L}^{-1}+$ BAP $2 \mathrm{mg} \mathrm{L}^{-1}, 2,4-\mathrm{D} 10 \mathrm{mg} \mathrm{L}^{-1}+$ BAP 0,5 mg L-1 dan 2,4-D $10 \mathrm{mg} \mathrm{L}^{-1}+$ BAP $1 \mathrm{mg} \mathrm{L}^{-1}$. Hasil kuantitatif zat goniotalamin dengan Kromatografi Cair Prestasi Tinggi terdapat pada perlakuan 2,4-D 5,0 $\mathrm{mgL}^{-1}+$ BAP $1 \mathrm{mg} \mathrm{L}^{-1}$ yaitu 9,57 $\mathrm{mg} \mathrm{g}^{-1}$.
\end{abstract}

Kata kunci: Goniothalamus tapis, Goniotalamin, 2,4-D, BAP, Kultur suspensi sel

\section{ABSTRACT}

The goniothalamine compound on Goniothalamus tapis is an alternative cancer medicine. This study aimed to obtain gonotalamin through callus culture and suspension cell culture. The experiment research method was Completely Randomized Design (CRD) with a combination of 2.4-D (1-10 $\left.\mathrm{mg} \mathrm{L}^{-1}\right)$ and BAP $\left(0.5-2 \mathrm{mg} \mathrm{L}^{-1}\right)$ using young stem explants consisting of 17 treatments with 3 replications. Data analysis used ANOVA and DMRT at $5 \%$. The results showed that G. tapis callus culture on $5.0 \mathrm{mg} \mathrm{L-1} \mathrm{2.4-D} \mathrm{+} 1 \mathrm{mg} \mathrm{L-1} \mathrm{BAP} \mathrm{was} \mathrm{the} \mathrm{best} \mathrm{treatment}$ medium with callus emergence time of 28.33 days and percentage of callus formation $100 \%$. The callus used for suspension cell culture was friable and greenish-yellow in color. Suspension cell culture resulted in rapid cell growth, was not fleshy, and easily separated. The quality test by Thin Layer Chromatography (TLC) from suspension cell culture resulted very clear, clean,

Cite this as: Mahadi, I., Wulandari, S., Safii, W., \& Sayuti, I. (2021). Kultur suspensi sel tanaman gajah beranak (Goniothalamus tapis Miq) terhadap kandungan zat goniotalamin. Jurnal Agro, 8(2), 247-261. https://doi.org/10.15575/14710 
and potential content of goniothalamin found in treatments 2.4-D $5.0 \mathrm{mg} \mathrm{L}^{-1}+\mathrm{BAP} 0.5 \mathrm{mg} \mathrm{L}^{-1}$, 2.4-D $5.0 \mathrm{mg} \mathrm{L}^{-1}+$ BAP $1 \mathrm{mg} \mathrm{L}^{-1}, 2.4-\mathrm{D} 5.0 \mathrm{mg} \mathrm{L}^{-1}+$ BAP $2 \mathrm{mg} \mathrm{L}^{-1}, 2.4-\mathrm{D} 10 \mathrm{mg} \mathrm{L}^{-1}+$ BAP $0.5 \mathrm{mg}^{-1}$ and 2.4-D $10 \mathrm{mg}^{-1}+\mathrm{BAP} 1 \mathrm{mg}^{-1}$. The quantitative results of the best goniotalamine compounds in cell suspension cultures using High-Performance Liquid Chromatography (HPLC) on medium 2,4-D $5.0 \mathrm{mgL}^{-1}+$ BAP $1 \mathrm{mg} \mathrm{L}^{-1}$ ie $9.57 \mathrm{~g}^{-1}$.

Keywords: Goniothalamus tapis, Goniothalamine, 2.4 D, BAP, Suspension cell culture

\section{PENDAHULUAN}

Provinsi Riau merupkan salah satu daerah dengan keanekaragaman hayati yang sangat beragam. Kondisi lahan yang subur dapat dimanfaatkan untuk membudidayakan tanaman obat oleh masyarakat. Salah satunya adalah tanaman obat gajah beranak (Goniothalamus tapis). Bagi masyarakat suku Sakai, tanaman ini digunakan sebagai obat setelah bersalin untuk membersihkan darah nifas. Tanaman ini juga biasa dimanfaatkan sebagai obat penurun panas, pereda maag, dan membantu pemulihan wanita bersalin. Bagian tanaman gajah beranak yang dapat digunakan meliputi batang, akar, daun, dan buah. Tanaman ini dapat dijadikan obat bagi kesehatan masyarakat.

Menurut Saunders (2003) tanaman gajah beranak (Goniothalamus tapis) merupakan tanaman pokok kecil atau perdu, berdaun lebar dengan permukaan licin dan mengkilat, memiliki bunga tunggal dengan 3 mahkota yang tumbuh dari batang atau ranting pohonnya, dalam satu karpel dapat berbuah 5-20 buah. Tanaman gajah beranak belum dibudidayakan. Tanaman ini tumbuh di kawasan hutan dataran rendah yang lembab dan dipingir aliran sungai (Mahadi, 2012). Mat \& Latiff (2002) menyatakan tanaman gajah beranak adalah sebagai hasil hutan yang mempunyai potensi sebagai sumber perobatan yang belum dikembangkan.
Tanaman jenis Goniothalamus tapis ini mengandung senyawa goniotalamin (Laily et al., 1992). Goniothalamin adalah suatu zat yang bersifat aktif biologi yang diekstrak dari tanaman Goniothalamus sp. Goniothalamin juga berperan dalam menghambat pertumbuhan maupun perkembangan sel kanker dalam jaringan tubuh menurut Azimahtol et al. (1993). Selanjutnya Wiart (2007) menjelaskan bahwa senyawa goniotalamin dapat digunakan sebagai anti kanker dan anti bakteria dalam pengobatan. goniotalamin juga bisa sebagai faktor pengaktif platelet mediator fosfolipid yang kuat yang menyebabkan pelebaran pembuluh darah serta mediator peradangan (Moharam et al., 2012). Permintaan bahan baku goniotalamin semakin meningkat untuk penelitian anti kanker, anti mikroba dan penghambat pertumbuhann janin sehingga perlu dilakukan peningkatan produksi melalui metode spesifik.

Tanaman gajah beranak sulit dikembangkan secara konvensional karena perkembangan embrio sangat lama untuk sampai ke fase pematangan dan banyak bijinya tidak menghasilkan embrio sehingga sulit berkecambah. Penelitian Mahadi (2012) mendapati bahwa tanaman gajah beranak berkecambah secara konvensional 8-12 bulan sedangkan menggunakan kultur jaringan hanya membutuhkan waktu 1-3 bulan untuk menjadi planlet. Penggunaan metode 
kultur jaringan dengan kultur kalus dan kultur suspensi sel adalah metode yang cepat guna memperoleh hasil bahan metabolit sekunder.

Hasil kajian Zaino et al. (2019) sebelumnya menjelaskan bahwa kultur kalus adalah langkah awal untuk memperoleh sel-sel yang muda dan giat membelah sebelum digunakan untuk pembiakan sel-sel ke dalam tahap kultur suspensi sel untuk menghasilkan bahan metabolit sekunder tanaman. Mahadi et al. (2016) juga menambahkan kulur kalus dapat dimanfaat sebagai pemilihan sel-sel potensi pada tanaman penghasil bahan metabolit sekunder baik seperti tanaman obat maupun tanaman penyengar sehingga perlu dikembangkan terlebih dahulu dengan metode kultur kalus supaya bahan metabolit sekunder yang diinginkan dapat dihasilkan lebih baik.

\section{BAHAN DAN METODE}

Penelitian Kultur suspensi sel Tanaman Gajah Beranak ini meliputi; kajian kultur kalus, kultur suspensi sel, ekstraksi goniotalamin, uji kualitas goniotalamin dengan Kromatografi Lapis Tipis (KLT) dan uji kuantitas goniotalamin dengan Kromatografi Cair Prestasi Tinggi (KCPT). Sampel tanaman gajah beranak (Goniothalamus tapis) yang diambil dari Hutan Ulayat Desa Cengar, Kecamatan Kuantan Mudik, Kabupaten Kuantan Singigi dan di Hutan Raya Sultan Syarif Kasim provinsi Riau.

Penelitian eksperimen rancangan Rancangan Acak Lengkap (RAL). Pada rancangan ini menggunakan 17 perlakukan media dengan 3 kali pengulangan. Media yang digunakan Murashige \& Skoog (MS) dengan penambahan kombinasi zat pengatur tumbuh (zpt) 2,4-Dicloropenoxy Acetic $(2,4$ D) dan Benzyl Amino Purin (BAP), yaitu: $\mathrm{D}_{0} \mathrm{~B}_{0}$ (tanpa zpt), $\mathrm{D}_{1} \mathrm{~B}_{0}$ (2,4-D 1 $\left.\mathrm{mg} \mathrm{L}^{-1}+\mathrm{BAP} 0 \mathrm{mg} \mathrm{L}^{-1}\right), \mathrm{D}_{1} \mathrm{~B}_{0,5}\left(2,4-\mathrm{D} 1 \mathrm{mg} \mathrm{L}^{-1}\right.$ + BAP 0,5 mg L-1 $), D_{1} B_{1}\left(2,4-D 1 \mathrm{mg} \mathrm{L}^{-1}+\right.$ BAP $\left.1 \mathrm{mg} \mathrm{L}^{-1}\right), \mathrm{D}_{1} \mathrm{~B}_{2}\left(2,4-\mathrm{D} 1 \mathrm{mg} \mathrm{L}^{-1}+\mathrm{BAP} 2\right.$ $\left.\mathrm{mg} \mathrm{L}^{-1}\right), \mathrm{D}_{3} \mathrm{~B}_{0}\left(2,4-\mathrm{D} 3 \mathrm{mg} \mathrm{L}^{-1}\right), \mathrm{D}_{3} \mathrm{~B}_{0,5}(2,4-\mathrm{D} 3$ $\left.\mathrm{mg} \mathrm{L}^{-1}+\mathrm{BAP} 0,5 \mathrm{mg} \mathrm{L}^{-1}\right), \mathrm{D}_{3} \mathrm{~B}_{1}\left(2,4-\mathrm{D} 3 \mathrm{mg} \mathrm{L}^{-}\right.$ $\left.{ }^{1}+\mathrm{BAP} 1 \mathrm{mg} \mathrm{L}^{-1}\right), \mathrm{D}_{3} \mathrm{~B}_{2}\left(2,4-\mathrm{D} 3 \mathrm{mg} \mathrm{L}^{-1}+\mathrm{BAP}\right.$ $\left.2 \mathrm{mg} \mathrm{L}^{-1}\right), \mathrm{D}_{5} \mathrm{~B}_{0}\left(2,4-\mathrm{D} 5 \mathrm{mg} \mathrm{L}^{-1}\right), \mathrm{D}_{5} \mathrm{~B}_{0,5}(2,4-\mathrm{D}$ $\left.5 \mathrm{mg} \mathrm{L}^{-1}+\mathrm{BAP} 0,5 \mathrm{mg} \mathrm{L}^{-1}\right), \mathrm{D}_{5} \mathrm{~B}_{1}(2,4-\mathrm{D} 5 \mathrm{mg}$ $\left.\mathrm{L}^{-1}+\mathrm{BAP} 1 \mathrm{mg} \mathrm{L}^{-1}\right), \mathrm{D}_{5} \mathrm{~B}_{2}\left(2,4-\mathrm{D} 5 \mathrm{mg} \mathrm{L}^{-1}+\right.$ BAP $\left.2 \mathrm{mg} \mathrm{L}^{-1}\right), D_{10} B_{0}\left(2,4-D 10 \mathrm{mg} \mathrm{L}^{-1}\right)$, $\mathrm{D}_{10} \mathrm{~B}_{0,5}\left(2,4-\mathrm{D} 10 \mathrm{mg} \mathrm{L}^{-1}+\right.$ BAP 0,5 $\left.\mathrm{mg} \mathrm{L}^{-1}\right)$, $D_{10} B_{1}\left(2,4-D 10 \mathrm{mg} \mathrm{L}^{-1}+B A P 1 \mathrm{mg} \mathrm{L}^{-1}\right)$ dan $D_{10} B_{2}\left(2,4-D 10 \mathrm{mg} \mathrm{L}^{-1}+\right.$ BAP $\left.2 \mathrm{mg} \mathrm{L}^{-1}\right)$. Eksplan yang digunakan batang muda (ex vitro).

Analisis kualitatif Goniotalamin dilakukan pada kultur kalus dan pokok induk. Parameter penelitian yaitu pertumbuhan sel kalus dan kandungan goniotalamin. Hasil kandungan goniotalamin dianalisis dengan ANOVA (Analysis of Variance) dan dilakukan uji lanjut dengan DNMRT (Duncan New Multiple Range Test) pada taraf 5\% untuk mengetahui tingkat signifikan. Tahap penelitian sebagai berikut :

\section{Kultur Kalus}

Eksplan yang digunakan pada kultur kalus adalah batang muda ex vitro yang berumur 3 bulan kemudian di potongpotong sepanjang $1 \mathrm{~cm}$ (Gambar 1). Selanjutkan eksplan di inisiasi pada dalam media perlakuan. Pengamatan 90 hari setelah kultur (HSK) Parameter kultur kalus yaitu waktu muncul kalus, persentase pembetukan kalus berdasarkan jumlah eksplan yang dikultur dan tekstur kalus . 


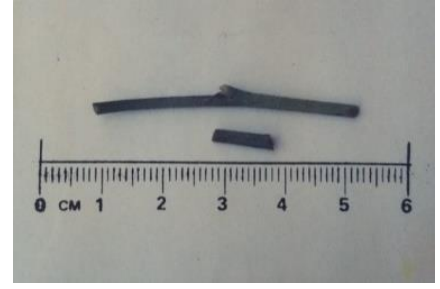

Gambar 1. Eksplan ex vitro batang muda tanaman gajah beranak

\section{Kultur Suspensi Sel}

Kultur suspensi sel dilakuan dengan memilih pertumbuhan yang terbaik pada perlakuan kultur kalus. Kalus yang digunakan pada kultur sel yaitu bertekstur remah (friable), muda, lembut dan mudah terurai pada media cair dan telah berumur 3 bulan. Sebanyak $3 \mathrm{mg}$ kalus dari masingmasing perlakuan disubkultur ke dalam media cair MS. Selanjutnya di goncang menggunakan shaker dengan kecepatan putaran $50 \mathrm{rpm}$ (Prasetyo et al., 2020). Kultur suspensi sel disubkultur setiap seminggu dan. dilakukan perhitungan pertumbuhan jumlah sel menggunakan Counter Cell . Pemanenan sel dilakukan saat pertumbuhan sel pada fase stationery. Selanjutnya dilakukan ekstraksi sel.

\section{Ekstraksi Goniotalamin}

Ekstraksi Goniotalamin menggunakan metode Jewers et al. (1972). Sampel sel kalus tersebut dikeringkan dengan oven pada suhu $\pm 50^{\circ} \mathrm{C}$ selama 24 jam dan dihaluskan. Masing-masing sebanyak 100 mg serbuk sampel sel kalus diektrak dengan menggunakan $1 \mathrm{ml}$ etanol $100 \%$. Ekstrak disonikasi selama 10 menit dan disentrifugasi pada $5000 \mathrm{rpm}$ dalam waktu 5 menit. Supernatan dipipet kemudian dimasukkan ke dalam tabung eppendorf 5 $\mathrm{ml}$ yang telah disediakan untuk hasil ekstrak. Langkah ini diulangi sehingga larutan sampel menjadi jenih. Sebanyak $200 \mu \mathrm{l}$ larutan ekstrak sel tanaman Gajah
Beranak diambil dan dikeringkan dengan nitrogen (N2). $1 \mathrm{ml}$ asetonitril (ACN) 100\% dicampurkan. Setelah itu diambil $100 \mu \mathrm{l}$ dan ditambahkan $900 \mu \mathrm{l}$ asetonitril 100\% sebagai pencairan.

\section{Analisis Kromatografi Lapis Tipis (KLT)}

Analisis kualitatif dilaksanakan dengan menerapakan metode Laily et al. (1992) yaitu penggunaan Pre-coated Thin Layer Chromatography (TLC Plat) atau Plat Kromatografi Lapis Tipis. Pelarut yang digunakan adalah petrolium eter dan ethyl acetat dengan perbandingan 1:1. Sebagai standar menggunakan goniotalamin murni, penetuan nilai Retention Factor (RF) atau Faktor Retensi yaitu nilai perbandingan jarak antar sampel pada plat KLT.

\section{Analisis Kromatografi Cair Prestasi Tinggi (KCPT)}

Analisis jumlah goniotalamin hasil ekstrasi kultur suspensi sel menggunakan metode Laily et al. (1992). Mengunakan kolom C18 (3,9 $\times 450 \mu \mathrm{m})$, Acetonitryl 40\%, $\mathrm{pH} \mathrm{5,8,} \mathrm{UV} 240 \mu \mathrm{m}$, kecepatan $1 \mathrm{~cm}$ per menit dan ukuran sampel 0,22 $\mu \mathrm{m}$. Alat dikalibrasi selama 30 menit, selanjutnya sampel diinjeksi dan pencatan setiap 8 menit. Setiap selesai run sampel dilakukan pencucian sebanyak 3 kali dengan acetonitryl 40\%. Puncak (Peak) kromatogram yang dihasilkan dicatat diolah menjadi data kuantitatif jumlah goniotalamin untuk sertiap perlakuan.

\section{HASIL DAN PEMBAHASAN}

\section{Waktu Muncul Kalus}

Pemberian kombinasi 2,4-D dan BAP menunjukkan pengaruh nyata terhadap waktu muncul kalus yang terbentuk pada eksplan, hal ini disebabkan oleh pemberian 
2,4-D dan BAP. Pada perlakuan yang hanya mengandung BAP saja kalus tidak terbentuk. Adapun data rata-rata hasil pengamatan waktu muncul kalus yang dinyatakan dalam Hari Setelah Kultur (HSK) disajikan pada Tabel 1.

Tabel. 1. Hasil kultur kalus tanaman Gajah Beranak (Goniothalamus tapis)

\begin{tabular}{|c|c|c|c|}
\hline $\begin{array}{c}\text { Kombinasi } \\
\text { perlakuan } \\
\text { 2,4-D BAP }\left(\mathrm{mg} / \mathrm{l}^{-1}\right)\end{array}$ & $\begin{array}{l}\text { Waktu Muncul } \\
\text { Kalus }\end{array}$ & $\begin{array}{l}\text { Pesentase } \\
\text { Pembentukan } \\
\text { Kalus (HSK) }\end{array}$ & $\begin{array}{c}\text { Tekstur Kalus } \\
\text { Warna }\end{array}$ \\
\hline $\mathrm{D}_{0} \mathrm{~B}_{0}$ & $0 \mathrm{~g}$ & $0 \mathrm{~d}$ & - \\
\hline $\mathrm{D}_{1} \mathrm{~B}_{0}$ & $0 \mathrm{~g}$ & $0 d$ & - \\
\hline $\mathrm{D}_{1} \mathrm{~B}_{0,5}$ & $0 \mathrm{~g}$ & $0 \mathrm{~d}$ & - \\
\hline $\mathrm{D}_{1} \mathrm{~B}_{1}$ & $0 \mathrm{~g}$ & $0 d$ & - \\
\hline$D_{1} B_{2}$ & $0 \mathrm{~g}$ & $0 \mathrm{~d}$ & - \\
\hline $\mathrm{D}_{3} \mathrm{~B}_{0}$ & $60,67 f$ & $60 c$ & Kompak, kehijauan \\
\hline $\mathrm{D}_{3} \mathrm{~B}_{0,5}$ & $45,33 \mathrm{e}$ & $60,33 \mathrm{c}$ & Kompak, kehijauan \\
\hline $\mathrm{D}_{3} \mathrm{~B}_{1}$ & $44,33 \mathrm{e}$ & $80,33 b$ & Agak Remah, kehijauan \\
\hline$D_{3} B_{2}$ & $43,00 \mathrm{e}$ & $80,67 \mathrm{~b}$ & Agak Remah, kehijauan \\
\hline $\mathrm{D}_{5} \mathrm{~B}_{0}$ & $44,67 e$ & $100 \mathrm{a}$ & Kompak, Hijau kekuningan \\
\hline $\mathrm{D}_{5} \mathrm{~B}_{0,5}$ & $37,33 \mathrm{de}$ & $100 \mathrm{a}$ & Remah, kuning kehijauan \\
\hline $\mathrm{D}_{5} \mathrm{~B}_{1}$ & $35,33 d$ & $100 \mathrm{a}$ & Remah, kuning kehijauan \\
\hline $\mathrm{D}_{5} \mathrm{~B}_{2}$ & $28,33 c$ & $100 \mathrm{a}$ & Remah, putih kekuningan \\
\hline $\mathrm{D}_{10} \mathrm{~B}_{0}$ & $40,67 b$ & $100 \mathrm{a}$ & Kompak, coklat \\
\hline $\mathrm{D}_{10} \mathrm{~B}_{0,5}$ & $35,67 a$ & $100 \mathrm{a}$ & Remah, kuning kecoklatan \\
\hline$D_{10} B_{1}$ & $37,33 a$ & $100 \mathrm{a}$ & Remah, putih kekuningan \\
\hline $\mathrm{D}_{10} \mathrm{~B}_{2}$ & $38,33 a$ & $100 \mathrm{a}$ & Lembek Berair, kuning kecoklatan \\
\hline
\end{tabular}

Ket: Angka yang diikuti dengan huruf berbeda menunjukkan beda nyata pada taraf $5 \%$ pada DNMRT $\alpha=0,05$, $\mathrm{D}=2,4-\mathrm{D} ; \mathrm{B}=\mathrm{BAP} ; \mathrm{HSK}=$ Hari setelah kultur

Hasil analisis statistik membuktikan bahwa perlakuan pada setiap kombinasi konsentrasi 2,4-D dengan BAP pengaruhnya berbeda nyata terhadap waktu munculnya kalus. Peningkatan laju pertumbuhan kalus pada tanaman gajah beranak dapat dilakukan dengan cara mengkombinasikan komposisi pada media tumbuh yang digunakan yaitu dilakukan penambahan zat pengatur tubuh yaitu fitohormon. Berdasarkan Tabel 1, rata-rata waktu muncul kalus kisaran antara 60,67 HSK hingga 28,33 HSK. Sedangkan pada perlakukan $\mathrm{D}_{0} \mathrm{~B}_{0}$ (kontrol), $\mathrm{D}_{1} \mathrm{~B}_{0}, \mathrm{D}_{1} \mathrm{~B}_{0,5}, \mathrm{D}_{1} \mathrm{~B}_{1}$ dan $D_{1} B_{2}$ kalus tidak terbentuk. Laju pertumbuhan kalus dipengaruhi oleh tingginya kosentrasi zpt yang diberikan secara kombinasi antara 2,4-D dan BAP ke dalam media perlakuan, kombinasi konsentrasi zpt yang semakin tinggi mempengaruhi laju pertumbuhan kalus. Rata-rata waktu tumbuh kalus yang paling lama terdapat pada perlakuan $\mathrm{D}_{3} \mathrm{~B}_{0}$ sebesar 60,67 HSK yang hanya mengandung 2,4-D saja dengan kosentrasi rendah seperti yang terlihat pada Gambar 2, hal ini menunjukkan bahwa kalus muncul pada waktu yang cukup panjang disebabkan oleh perlakuan tersebut hanya ditambahkan 3 $\mathrm{mgl}^{-1}$ 2,4-D, sehingga dalam peningkatan pertumbuhan kalus belum optimal. Hal ini ditunjukkan dengan konsentrasi zpt yang meningkat. Pada perlakuan $\mathrm{D}_{0} \mathrm{~B}_{0}$ (kontrol), $\mathrm{D}_{1} \mathrm{~B}_{0}, \mathrm{D}_{1} \mathrm{~B}_{0,5}, \mathrm{D}_{1} \mathrm{~B}_{1}$ dan $\mathrm{D}_{1} \mathrm{~B}_{2}$ disebabkan zpt belum dapat merangsang pembelahan sel dan hormon endogen berupa auksin dan 
sitokinin yang terkandung dalam eksplan tidak mampu memicu sel dalam berkembang dan replikasi, karena ketidakpastian jumlah hormon yang tersedia. Kalus yang terbentuk sangat dipengaruhi oleh konsentrasi dan jenis hormon yang digunakan. Keseimbangan dan interaksi fitohormon yang ada dalam eksplan yang diserap media perlu dikendalikan untuk pertumbuhan dan morfogonesis secara in vitro. Menurut Agarwal (2015) penambahan konsentrasi hormon akan mempercepat pembentukan kalus.

Sedangkan pada perlakuan $\mathrm{D}_{5} \mathrm{~B}_{1}$ menunjukkan waktu rata-rata muncul kalus gajah beranak yang paling cepat sebesar 28,33 HSK seperti yang terlihat pada Gambar 2. Hal itu disebabkan pengaruh penambahan 2,4-D pada media cukup efektif dalam meningkatan laju pertumbuhan kalus. Peningkatan laju pertumbuhan kalus disebabkan oleh peningkatan konsentrasi 2,4-D.

Perlakuan 2,4-D yang ditambahkan di medium bisa meningkatkan sintesis protein, permeabilitas sel terhadap air, plastisitas, tekanan osmotik yang naik, dan pengembangan dinding sel serta menyebabkan tekanan dinding sel berkurang. Pemberian auksin berpengaruh terhadap pegembangan dan plastisitas dinding sel, hal ini disebabkan auksin menghasilkan $\mathrm{H}^{+}$pada dinding sel sehingga $\mathrm{pH}$ dinding sel menjadi turun dan terjadi pelonggaran struktur dinding sel. Auksin memiliki peran untuk menginduksi kalus namun penambahan sitokinin dalam media dapat berperan dalam menginduksi pembelahan sel. Pembentukan kalus dapat dipicu dengan penambahan auksin. Apabila auksin pada media lebih tinggi dibandingkan sitokinin dapat memacu regenerasi eksplan dalam membentuk kalus juga memacu pembentukan akar (Fazeli-Nasab, 2018)
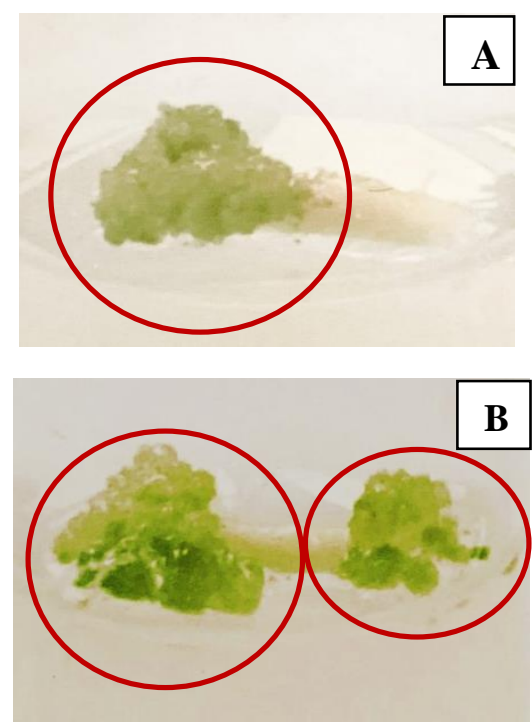

Gambar 2. Kalus Gajah Beranak yang lama terbentuk pada perlakuan $\mathrm{D}_{3} \mathrm{~B}_{0}$ (A) dan Kalus Gajah Beranak yang tercepat pada perlakuan $\mathrm{D}_{5} \mathrm{~B}_{2}(\mathrm{~B})$

\section{Persentase Terbentuk Kalus}

Persentase terbentuknya kalus pada tanaman gajah beranak dihitung berdasarkan kalus yang terbentuk pada setiap eksplan yang dikultur dari setiap perlakuan. Selanjutnya kalus yang sudah tumbuh dilakukan sub kultur dengan mengambil kalus dan dipindahkan pada media yang baru agar pertumbuhan kalus dapat berkembang. Sistem induksi pada media perlakuan yang sesuai dan tepat dapat merangsang kalus tanaman Gajah beranak dapat tumbuh dan berkembang. Hasil rata-rata persentase terbentuknya kalus pada induksi eksplan Goniothalamus tapis dapat dilihat pada Tabel 1.

Hasil uji ANOVA memperlihatkan pemberian 2,4-D dan BAP memberikan pengaruh nyata terhadap pertumbuhan 
eksplan dalam membentuk kalus. Perlakuan $D_{5} B_{0}$ hingga $D_{10} B_{2}$ membentuk persentase tumbuh eksplan hingga $100 \%$ eksplan yang digunakan yaitu jaringan muda. Jaringan ini memiliki hormon endogen yang aktif dan bersifat maristematik, salah satu jenis auksin yang efektif dalam menginduksi pembentukkan kalus yaitu 2,4-D. Menurut Shehzad et al. (2021) bahwa hormon sitokinin juga dibutuhkan dalam merangsang proliferasi sel kalus.

Perlakuan $D_{3} B_{0}, \quad D_{3} B_{0,5}, \quad D_{3} B_{1}$ dan $D_{3} B_{2}$ memperlihatkan rata-rata persentase jumlah kalus tanaman Gajah Beranak lebih rendah yaitu sekitar 58,33\% - 80,33\%, hal ini disebabkan karena pemberian 2,4-D yang rendah dan kosentrasi BAP yang tinggi tidak dapat merangsang pembentukan kalus yang maksimal. Konsentrasi hormon sitokinin yang lebih tinggi dan konsentrasi auksin yang rendah menyebabkan kalus yang terbentuk hanya sedikit.

Pada perlakuan $D_{5} B_{0}$ hingga $D_{10} B_{2}$ menghasilkan kalus $100 \%$ dari eksplan batang muda, hal ini disebabkan auksin berada dibawah permukaan batang. Menurut Fazeli-Nasab (2018) BAP yang ditambahkan bersama dengan 2,4-D dapat membantu merangsang pembentukan kalus, produksi kalus yang maksimal terhadap bobot kalus, jumlah kalus dan warna kalus untuk yang dapat diteruskan pada proses kultur suspensi sel.

\section{Tekstur Kalus}

Kalus pada tanaman gajah beranak dapat dikatakan baik apabila memiliki tekstur remah (friable). Tekstur kalus yang remah dapat membantu dalam pemisahan sel menjadi sel-sel tunggal pada kultur suspensi dan meningkatkan aerasi oksigen antar sel. Tekstur kalus terdiri dari padat/kompak (compac), agak remah (intermediet), remah (friable) dan lembek berair (fleshy). Hasil pengamatan tentang tekstur kalus disajikan pada Tabel 1.

Berdasarkan hasil pengamatan yang dilakukan bentuk tekstur kalus yang muncul pada setiap perlakuan dengan kombinasi 2,4-D dan BAP bertekstur kompak, remah hingga berair dengan warna yang bervariasi dari berwarna hijau hingga berwarna kuning kecoklatan seperti terlihat pada Gambar 3. Warna pada kalus yang berbeda menunjukkan tingkat perkembangan kalus yang berbeda-beda, hal ini dipengaruhi oleh konsentrasi fitohormon yang diberikan pada media kultur. Tekstur pada kalus yang bervariasi dari padat sampai meremah dan berair dipengaruhi oleh komposisi nutrient pada media, jenis tanaman yang digunakan, dan zat kondisi lingkungan kultur serta zat pengatur tumbuh.

Kalus tekstur friable merupakan sekumpulan sel yang mudah terpisah yang terdapat pada media perlakuan $D_{5} B_{0,5}, D_{5} B_{1}$, $D_{5} B_{2}, D_{10} B_{0,5}$ dan $D_{10} B_{1}$. Terbentuknya kalus yang bertekstur remah pada media kultur selain dengan adanya tambahan kombinasi 2,4-D dan BAP yang seimbang ini juga dipengaruhi oleh auksin endogen yang diproduksi secara internal oleh eksplan batang muda dari tanaman gajah beranak. Keseimbangan kemampuan sel tanaman dalam memanfaatkan nutrisi secara maksimal di dalam sel, dalam proses metabolisme dan sintesa protein yang aktif akan menghasilkan sel-sel yang cepat membelah dan menghasilkan bahan metabolit yang banyak. Pembelahan sel yang cepat terjadi yaitu dari tekstur kalus kompak menjadi tekstur kalus remah. Salah satu ciri khusus dari sel kalus yang 
remah yaitu berpisahnya antar sel. Apabila kalus diambil menggunakan pinset maka kalus akan menempel dan mudah disubkultur.
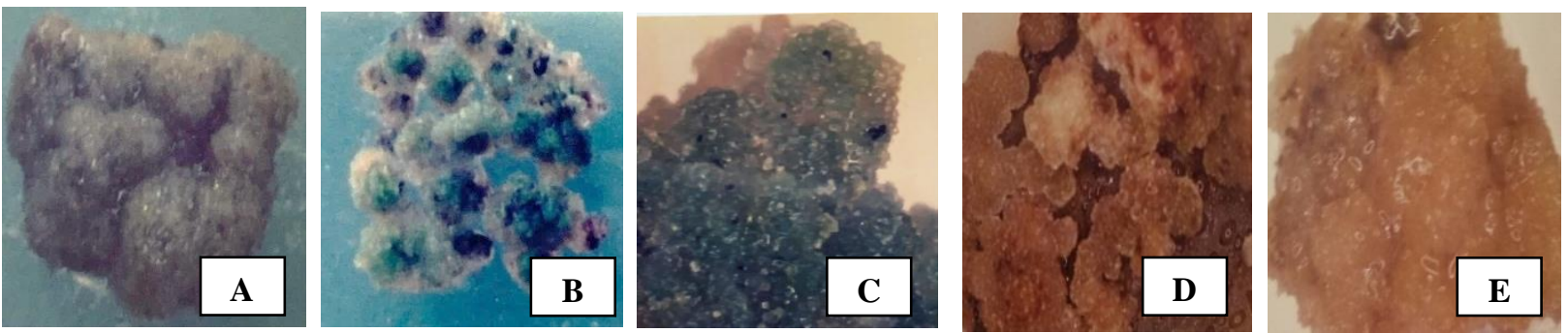

Gambar 3. Tekstur kalus yang dibentuk pada setiap perlakuan: A. Tektur padat (Kompak) berwarna kehijauan perlakuan $D_{3} B_{0}, D_{3} B_{0,5}, D_{5} B_{0}, B$. Tekstur semi remah (Intermediet) berwarna kehijauan perlakuan $\mathrm{D}_{3} \mathrm{~B}_{1}, \mathrm{D}_{3} \mathrm{~B}_{2} \mathrm{C}$. Tektur remah (friable) berwarna hijau muda perlakuan $D_{5} B_{0,5}, D_{5} B_{1}, D_{5} B_{2}, D_{10} B_{1}$, D. Tekstur remah (friable) kuning kecoklatan perlakuan $\mathrm{D}_{10} \mathrm{~B}_{0,5}$, E. Kalus lembek berair (fleshy) pada $\mathrm{D}_{10} \mathrm{~B}_{2}$.

Pada perlakuan $D_{3} B_{0}, D_{3} B_{0,5}, \quad D_{5} B_{0}$ dan $\mathrm{D}_{10} \mathrm{~B}_{0}$ kalus yang terbentuk mengalami lignifikasi sehingga kalus tersebut mempunyai tekstur yang keras dan kompak. Tekstur kalus kompak adalah pengaruh hormon sitokinin yang bermanfaat dalam transport zat hara. Air dan zat hara akan dibawa melalui pembuluh pengangkut dari bagian basal (sistem transport pada sitokinin) menuju apeks dan akan mempengaruhi potensial osmotik dalam sel. Sukrosa yang ditambahkan pada media melalui pembuluh floem akan mengalir dan menyebabkan tekanan turgor. Menurut Mishra et al. (2019) tekanan turgor pada tranportasi sel tanaman terjadi secara osmosis karena adanya konsentrasi larutan yang berbeda, hal ini akan mengakibatkan sukrosa dan air pada media masuk ke dalam sel sehingga dinding sel akan semakin kaku dan sel kalus menjadi padat atau kompak. Kashyap et al. (2016) menjelaskan jika hanya auksin saja yang terdapat pada media dapat menyebabkan lignifikasi dan kalus akan bertektur kompak, sehingga perlu adanya kombinasi antara auksin dan sitokinin dalam menghasilan kalus yang bertektur remah.
Pertumbuhan kalus yang baik dapat dilihat melalui warna kalus, apabila terdapat pigmen kuning maupun putih maka pertumbuhan kalus berjalan dengan baik. Menurut Zainol et al. (2019) sel kalus yang memiliki pigmen putih mengadung polisakarida berupa pati yang dimanfaatkan sebagai sumber bahan penghasil energi bagi sel pada saat umur sel muda yang bersifat meristematik, sedangkan pigmen kuning hasil dari penumpukan glukosa dari proses fotosistesis dan sel giat membelah dan penumpukan klorofil terjadi seiring sel umur semakin tua.

Respon eksplan gajah beranak yang berasal dari media dengan penambahan 2,4-D yang tinggi mempunyai tekstur yang remah dan warna yang dominan yaitu putih kehijauan sedangkan yang bertektur kompak berwarna hijau karena kalus mengandung klorofil, hal ini diakibatkan adanya interaksi 2,4-D dan BAP membantu pembentukan zat hijau daun pada kalus dan faktor lingkungan yang mempengaruhi yaitu cahaya yang dipancarkan. Kalus yang warna kuning keputihan mengandung plastid dan tidak memiliki kloroplas. Menurut Farhadi et al. (2017) menyatakan 
bahwa saat induksi kalus berlangsung, maka peranan cahaya mempengaruhi proses fotosintesis sehingga merangsang pembentukan kloroplas yang menghasilkan klorofil dan ini akan membantu pembelahan sel kalus menjadi lebih banyak. Pada awal kalus terbentuk berwarna putih bening menjadi kuning dan akhirnya kehijauan hingga hijau seiring semakin lamanya kalus terkena cahaya maka jumlah plastida yang dihasilkan semakin meningkat. Plastida yang berisi butir pati secara perlahan akan tumbuh menjadi sistem membran dan membentuk butir-butir klorofil dengan bantuan cahaya menyebabkan kalus menjadi berwarna hijau menurut Shehzad et al. (2021). Cahaya kuning keputihan dapat merangsang pembentukan kalus dan organogenesis dalam kultur jaringan tanaman.

Pada semua perlakuan yang menghasilkan kalus pertumbuhannya semakin menurun dan tidak bertahan lama kemudian mati secara perlahan. Terjadi perubahan warna menjadi coklat (browning) ada minggu ke 24 karena pada masa perkembangan kalus yang semakin lama dapat terjadi degradasi secara fisiologis yang diakibatkan oleh unsur hara atau hormonnya berkurang. Browning merupakan salah satu tanda terjadinya penurunan fisiologis eksplan dan sintesis senyawa fenol. Perubahan warna ini terjadi karena umur sel atau jaringan pada yang semakin bertambah. Menurut (Marisol Ochoa-Villarreal et al. (2016), metabolisme senyawa fenol yang bersifat toksik dan terangsang karena proses sterilisasi eksplan sehingga dapat menghambat pertumbuhan maupun kematian pada jaringan dan memberikan warna coklat pada kalus. Oleh sebab itu perlu dilakukan subkultur sebelum nutrisi berkurang pada media yang mengakibatkan perumbuhan sel menurun bahkan mati.

\section{Analisis Kualitatif Kandungan Goniotalamin menggunakan Kromatografi Lapis Tipis (KLT)}

Analisis kualitatif goniotalamin dilakukan terhadap media perlakukan yang menghasilkan kalus. Hasil uji KLT dari kultur kalus tanaman Goniothalamus tapis menunjukkan bahwa kandungan goniotalamin untuk semua sampel kalus dari semua media perlakukan menghasilkan nilai Rf antara 0,77-0,79. Nilai Rf goniothamin murni adalah 0,79 sebagai standar acuan, ini membuktikan bahwa semua sampel ternyata memiliki angka yang mendekati atau sama dengan nilai standar goniothalamin. Hasil nilai ini menandakan semua sampel mengandung senyawa goniothalamin. Ketajaman warna juga menunjukan tiap perlakuan mengandung goniothalamin yang berbeda.

Tumpukan semua eksplan batang kultur kalus pada perlakuan $D_{5} B_{1}$ dan $D_{5} B_{2}$, menunjukan warna pada plat KLT yang sangat jelas, hal ini membuktikan bahwa kandungan goniotalamin dalam kajian ini berbeda dengan ketajaman warna pada plat KLT yang dihasilkan. Semakin jelas dan cerah serta memiliki niai Rf yang sama atau mendekati nilai Rf goniothalamin strandar maka hal ini menunjukkan kandungan goniothalamin yang tinggi. Keadaan ini menjelaskan bahwa di dalam kultur kalus mengandung goniothalamin. Kualitas warna yang dihasilkan oleh plat KLT akan mengindikasi tingginya kandungan suatu zat yang ada di dalamnya pada kultur kalus tanaman gajah beranak. Keberadaan zat goniothalamin dapat disajikan pada Tabel 2. 
Tabel 2. Keberadaan goniotalamin dengan Kromatografi Lapis Tipis (KLT) pada perlakuan 2,4-D dan BAP pada tanaman gajah beranak

\begin{tabular}{cccc}
\hline $\begin{array}{c}\text { Perlakuan } \\
\text { 2,4-D dan BAP }\left(\mathbf{m g ~ l}^{-\mathbf{1}}\right)\end{array}$ & $\begin{array}{c}\text { Keberadaan } \\
\text { Goniotalamin }\end{array}$ & $\begin{array}{c}\text { Kualitas } \\
\text { Warna }\end{array}$ & $\begin{array}{c}\text { Indikasi } \\
\text { Kadungan } \\
\text { Goniotalamin }\end{array}$ \\
\hline $\mathrm{D}_{3} \mathrm{~B}_{0}$ & $\mathrm{Ada}$ & Kabur & Sedikit \\
$\mathrm{D}_{3} \mathrm{~B}_{0,5}$ & $\mathrm{Ada}$ & Kabur & Sedikit \\
$\mathrm{D}_{3} \mathrm{~B}_{1}$ & $\mathrm{Ada}$ & Kabur & Sedikit \\
$\mathrm{D}_{3} \mathrm{~B}_{2}$ & $\mathrm{Ada}$ & Kabur & Sedikit \\
$\mathrm{D}_{5} \mathrm{~B}_{0}$ & $\mathrm{Ada}$ & Kabur & Sedikit \\
$\mathrm{D}_{5} \mathrm{~B}_{0,5}$ & $\mathrm{Ada}$ & Jelas & Banyak \\
$\mathrm{D}_{5} \mathrm{~B}_{1}$ & $\mathrm{Ada}$ & Sangat Jelas & Sangat Banyak \\
$\mathrm{D}_{5} \mathrm{~B}_{2}$ & $\mathrm{Ada}$ & Sangat Jelas & Sangat Banyak \\
$\mathrm{D}_{10} \mathrm{~B}_{0}$ & $\mathrm{Ada}$ & Kabur & Sedikit \\
$\mathrm{D}_{10} \mathrm{~B}_{0,5}$ & $\mathrm{Ada}$ & Jelas & Banyak \\
$\mathrm{D}_{10} \mathrm{~B}_{1}$ & $\mathrm{Ada}$ & Jelas & Banyak \\
$\mathrm{D}_{10} \mathrm{~B}_{2}$ & $\mathrm{Ada}$ & Kabur & Sedikit \\
\hline
\end{tabular}

Berdasarkan Tabel 2, perlakuan $D_{1} B_{0}$ dan $D_{1} B_{0,5}$ menunjukan tidak adanya keberadaan goniotalamin karena tidak ditemukan noktah atau tumpukan warna biru yang mendekati nilai Rf goniotalamin murni (standar). Perlakuan $\mathrm{D}_{5} \mathrm{~B}_{1}$ dan $\mathrm{D}_{5} \mathrm{~B}_{2}$ menunjukkan noktah dengan warna sangat jelas dan diperkirakan banyak mengandung goniothalamin berbanding perlakuan media lainnya. Perlakuan $D_{3} B_{0}$, $D_{3} B_{0,5}, \quad D_{3} B_{1}, \quad D_{3} B_{2}, \quad D_{5} B_{0} \quad$ dan $\quad D_{10} B_{2}$ menunjukan warna kabur pada plat KLT, hal ini menghasilkan goniotalamin sedikit. Dari semua perlakuan hanya 5 media yang dapat diteruskan ke kultur suspensi sel berdasarkan tekstur dan potensi kandungan goniotalamin dari kategori banyak hingga kategori sangat banyak yakni pada media perlakuan $D_{5} B_{0,5}, D_{5} B_{1}$, $D_{5} B_{2}, D_{10} B_{0,5}$ dan $D_{10} B_{1}$. Dengan demikian dapat dilakuan kajian kuantitatif pada kandungan zat goniotalamin pada kultur sel dengan menggunakan Kromatografi Cair Prestasi Tinggi (KCPT).

\section{Kultur Suspensi Sel}

Pertumbuhan sel kalus yang baik dan cepat merupakan syarat untuk dilanjutkan ke kultur suspensi sel guna mendapatkan zat metabolit sekunder tanaman. Menurut Robles-Martínez et al. (2016) menyatakan bahwa sel kalus yang bersifat remah, mudah terurai, pertumbuhannya cepat merupakan kalus yang sesuai untuk kultur suspensi sel. Hasil kultur kalus yang sesuai dengan karateriktik kalus yang dapat dilanjutkan ke kultur suspensi sel yaitu pada media perlakuan $D_{5} B_{0,5}, D_{5} B_{1}, D_{5} B_{2}$, $\mathrm{D}_{10} \mathrm{~B}_{0,5}$ dan $\mathrm{D}_{10} \mathrm{~B}_{1}$ (Gambar 4).

Kalus bertektur remah tanaman Gajah Beranak yang digunakan untuk kultur suspensi sel sebanyak $30 \%$. Adapun perlakuan tersebut adalah $D_{5} B_{0,5}, D_{5} B_{1}, D_{5} B_{2}$, $D_{10} B_{0,5}$ dan $D_{10} B_{1}$ yang menghasilkan kalus remah yang lebih baik diantara perlakuan lain. Kalus yang didapatkan pada kombinasi ini mudah dipisahkan dan juga memiliki tekstur yang sangat remah serta memiliki kandungan air yang sedikit seperti yang terlihat pada Gambar 4. 


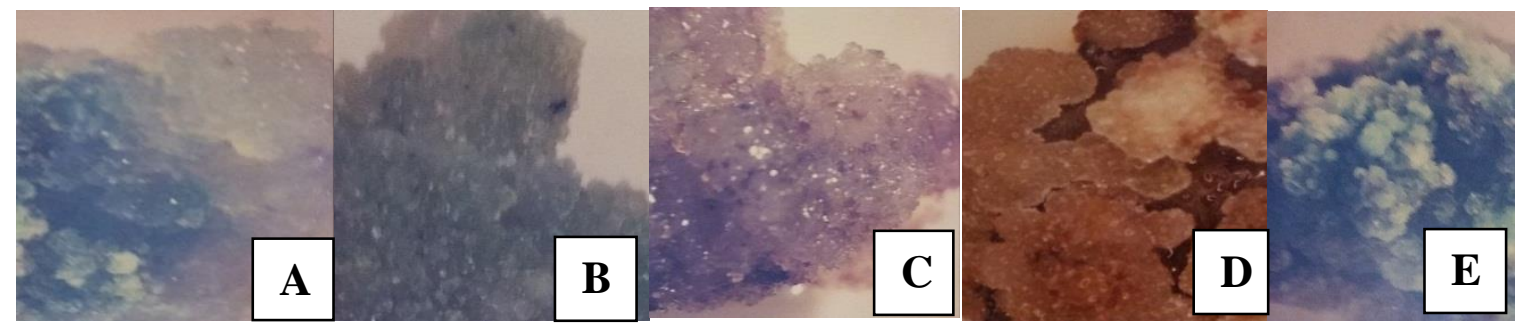

Gambar 4. Kalus yang bertektur Remah (Friable) yang digunakan pada kultur suspensi sel A. Perlakukan $D_{5} B_{0,5}$, B. Perlakuan $D_{5} B_{1}$, C. Perlakuan $D_{5} B_{2}$, D. Perlakuan $D_{10} B_{0,5}$, dan $E$. Perlakuan $\mathrm{D}_{10} \mathrm{~B}_{1}$

Hasil pertumbuhan sel pada kultur suspensi sel yaitu Perlakuan $D_{5} B_{1}\left(5,0 \mathrm{mg} \mathrm{l}^{-1}\right.$ 2,4-D+1 $\mathrm{mg} \mathrm{l}^{-1}$ BAP) lebih cepat dan banyak menghasilkan jumlah sel yaitu $94,7 \times 10^{3} \mathrm{~m}$ $\mathrm{I}^{-1}$ setelah pengkulturan 12 minggu dibandingkan dengan media lainnya. Selanjutnya diikuti dengan perlakuan $\mathrm{D}_{5} \mathrm{~B}_{2}$ jumlah sel sebanyak $80,4 \times 10^{3} \mathrm{ml}^{-1}, \mathrm{D}_{10} \mathrm{~B}_{0,5}$ jumlah sel yaitu $59,8 \times 10^{3} \mathrm{ml}^{-1}, \mathrm{D}_{5} \mathrm{~B}_{0,5}$ jumlah sel yaitu $51,4 \times 10^{3} \mathrm{ml}^{-1}$ dan $\mathrm{D}_{10} \mathrm{~B}_{1}$ jumlah sel yaitu 45,3 $\times 10^{3} \mathrm{ml}^{-1}$ (Gambar 5). Ukuran sel yang dihasilkan oleh masingmasing perlakuan juga bervariasi yaitu dari $1 \mathrm{~mm}$ hingga ke $5 \mathrm{~mm}$ (Gambar 6).

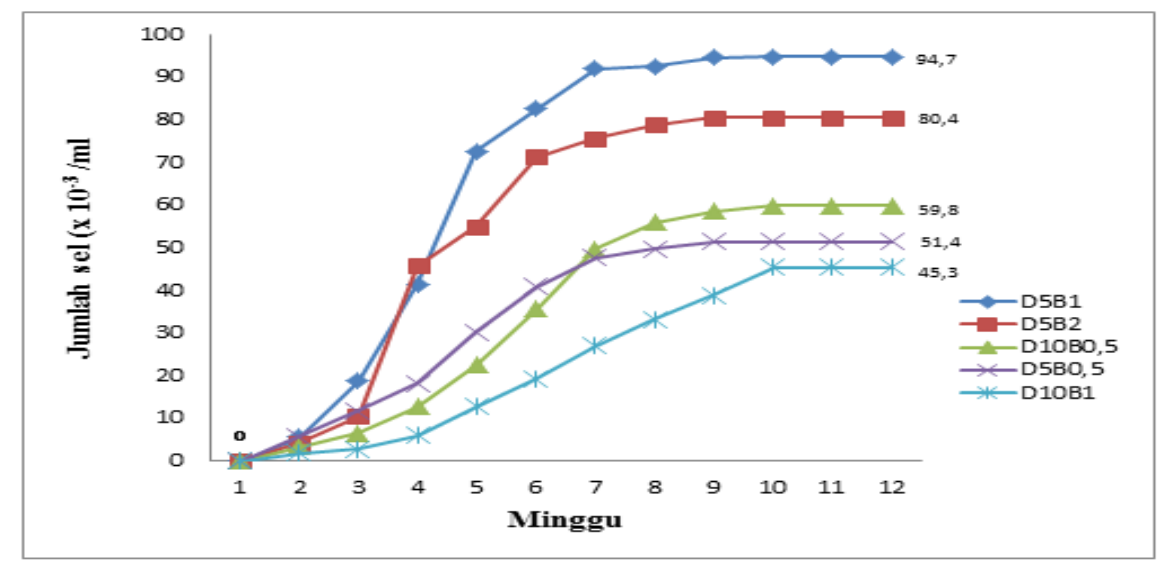

Gambar 5. Grafik pertumbuhan sel gajah beranak setelah 24 minggu pengkulturan

Pada media perlakuan $D_{5} B_{1}$ ukuran sel lebih seragam yang agregatnya kecil yaitu 0,1-1 $\mathrm{mm}$, sedangkan pada perlakuan $\mathrm{D}_{5} \mathrm{~B}_{2}$ yaitu $0,1-2 \mathrm{~mm}, D_{10} B_{0,5}$ yaitu $0,3-1,5 \mathrm{~mm}$, $D_{5} B_{0,5}$ yaitu $0,5-2 m m$ dan $D_{10} B_{1}$ yaitu 1 $5 \mathrm{~mm}$. Pemberian ZPT yang sesuai dalam kultur sel ke dalam media cair dengan karakter suatu tanaman akan memberi respon yang baik terhadap pertumbuhan dan perkembangan pembelahan sel secara mitosis yang berdampak pada jumlah dan ukuran agregat sel kultur secara keseluruhan Mahadi et al. (2016) Sebaran sel tersedia lebih merata dengan gabungan sel yang kecil yaitu 1-2 mm. Keseluruhan sel yang dihasilkan pada akhir fase stationer berwana hijau. Perubahan warna ini terjadi saat sel memasuki fase stasioner.

Pada media perlakuan $D_{5} B_{1}$, produksi sel adalah cepat berbanding perlakuan lainnya karena sifat kalus yang dihasilkan dari kultur kalus adalah remah dan mudah terurai sehingga memudahkan sel-sel tersuspensi dalam media cair kultur. Dan 
mungkin sel-sel yang terlibat dalam proliferasi adalah sel-sel parenkim yang terdapat pada kortek. Sel-sel ini adalah selsel yang paling giat membelah. Dari Penelitian kadar pertumbuhan sel, didapati bahwa masa fase lag untuk media $D_{5} B_{1}$ adalah lebih cepat yaitu 5-7 hari setelah inokulasi sel ke dalam media, karena kalus yang diperoleh adalan bersifat muda, yang diambil dari bagian atas kalus berwarna kuning muda yang paling baik pertumbuhannya. Salanjutnya diambil pada sub kultur sel sewaktu fase linear. Menurut Marisol Ochoa-Villarreal et al. (2016), kadar pertumbuhan sel pada kultur suspensi akan lebih tinggi jika sel diperoleh dari stok inokulasi yang giat membelah pada fese linear.

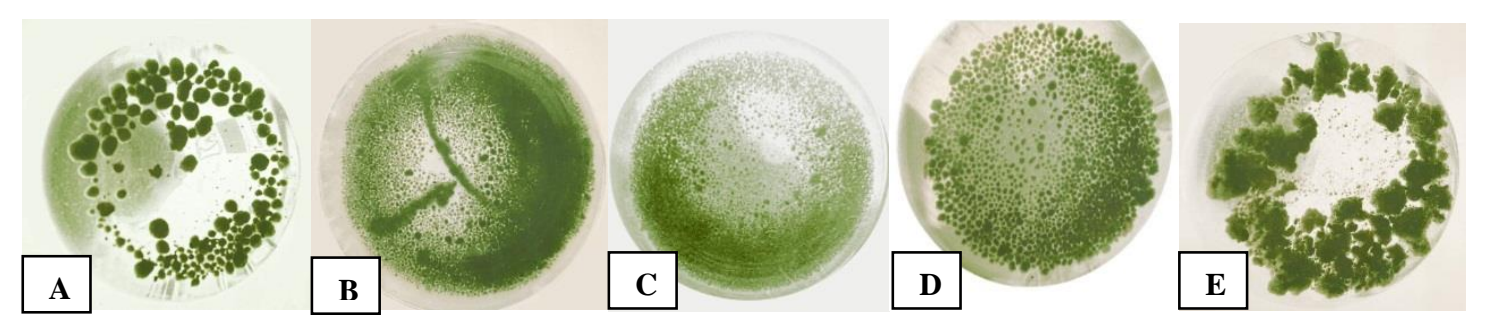

Gambar 6. Ukuran sel yang dihasilkan pada kultur suspense sel gajah beranak (Goniothalamus tapis). A. Perlakuan $\mathrm{D}_{5} \mathrm{~B}_{0,5}$ ukuran sel $0,5-2 \mathrm{~mm}$, B. Perlakuan $D_{5} B_{1}$ ukuran sel 0,1-1, C. Perlakuan $D_{5} B_{2}$ ukuran sel 0,1-2 mm mm, D. Perlakuan $D_{10} B_{0,5}$ ukuran sel 0,3-1,5 mm, E. Perlakuan $D_{10} B_{1}$ ukuran sel 1$5 \mathrm{~mm}$.

Pada media $D_{5} B_{1}, D_{5} B_{2}, D_{10} B_{1}$ variasi sel yang dihasilkan lebih heterogen pada subkultur kedua, mungkin disebabkan kadar pertumbuhan sel pada eksplan batang sangat cepat di tahap awal, sehingga fase linear yang dilalui singkat, sel tidak bertambah, tetapi ukuran sel semakin bertambah ketika berada dalam fase stationer (fase tetap). Pada keadaan seperti ini, perlu dilakukan subkultur lebih awal yaitu minggu ke 3 berbanding pada media $D_{5} B_{0,5}$ dan $D_{10} B_{1}$, karena fase linear sangat singkat sehingga diharapkan sel-sel yang homogen dapat diperoleh. Menurut Açikgöz et al. (2019) ekplan batang terutama pada bagian prokabium banyak mengandung auksin yang merupakan tempat penyimpanan bahan sel prokabium tumbuhan yang bersifat meristematik. Hal ini yang menyebabkan kadar pertumbuhan sel pada batang meningkat.

\section{Analisis Kuantitatif Goniothalamin (Kromatografi Cair Prestasi Tinggi/KCPT)}

Ektraksi kultur suspensi sel untuk mengetahui jumlah kuantitatif kandungan giniotalamin dilakukan setelah sel dalam fase stationery yaitu umur 12 minggu setelah kultur atau umur kultur sel suspensi sudah 3 bulan. Hasil dari analisis KCPT didapati bahwa kandungan goniotalamin tanaman gajah beranak pada masing-masing perlakuan media $D_{5} B_{0,5}$, $D_{5} B_{1}, D_{5} B_{2}, D_{10} B_{0,5}$ dan $D_{10} B_{1}$ kultur suspensi sel mengandung ganiotalamin yang berdabeda (Tabel 3). Perlakuan $D_{5} B_{1}$ mengahasilkan kandungan goniotalamin yang tinggi yaitu $9,57 \mathrm{mg} / \mathrm{g}$ dengan kategori sangat banyak berbanding perlakuan $D_{5} B_{0,5}, D_{5} B_{2}, D_{10} B_{0,5}$ dan $D_{10} B_{1}$.

Tingginya kandungan goniotalamin perlakuan media $D_{5} B_{1}$ pada kultur suspensi sel kemungkinan hal ini dikarenakan 
adanya kadar pertumbuhan dan pembelahan sel yang tinggi sebagai pemberian yang seimbang 2,4-D dan BAP. Kadar pertumbuhan sel dalam kultur suspensi sel adalah lebih tinggi dengan penambah hormon eksogen yang optimal karena media cair yang digunakan dapat menyentuh semua permukaan sel, sehingga sel dapat menyerap nutrisi dan memanfaatkan hormon dari luar sel lebih banyak. Pori-pori sel dengan leluasa secara difusi dapat mengisap nutrisi yang ada pada media cair tersebut. Semakin banyak jumlah sel yang dihasilkan kemungkinan semakin banyak pula zat metabolit sekunder yang dihasilkan. Di samping itu, sel lebih banyak terbaur dalam media cair tersebut sehingga kesempatan sel untuk menyerap nutrisi lebih tinggi berbanding kultur kalus. Akan tetapi hasil ini jika dibandingkan dengan kandungan goniotalamin pada pokok induk masih lebih rendah. Hal ini berkaitan dengan proses regulasi reaksi biosistesis giniotalamin tersebut dalam sel-sel tumbuhan.

Tabel 3. Hasil ekstrak goniotalamin dari kultur jaringan eksplan Goniothalamus tapis dengan menggunnakan KCPT

\begin{tabular}{lccc}
\hline Perlakuan & $\begin{array}{r}\text { Berat Ekstrak } \\
\mathbf{( g )}\end{array}$ & $\begin{array}{c}\text { Kandungan } \\
\text { Goniotalamin } \\
\left(\mathbf{m g ~ g}^{-1}\right)\end{array}$ & Keterangan \\
\hline $\mathrm{D}_{5} \mathrm{~B}_{0,5}$ & 1 & 1,20 & Sangat Sedikit \\
$\mathrm{D}_{5} \mathrm{~B}_{1}$ & 1 & 9,57 & Sangat Banyak \\
$\mathrm{D}_{5} \mathrm{~B}_{2}$ & 1 & 6,78 & Banyak \\
$\mathrm{D}_{10} \mathrm{~B}_{0,5}$ & 1 & 3,65 & Sedikit \\
$\mathrm{D}_{10} \mathrm{~B}_{1}$ & 1 & 5,42 & Banyak \\
\hline
\end{tabular}

Menurut Kashyap et al. (2016) bahan metabolit sekunder disintesis oleh organorgan tertentu seperti sel-sel parenkim namun penumpukan bahan metabolit sekunder ini sering terjadi pada sel-sel tumbuhan dewasa yang telah mengalami difrensiasi. Pada kajian ini, sel-sel dalam kultur suspensi $G$. tapis adalah sel yang dalam masa proses pembelahan sel dengan cepat dan belum mencapai tingkat difrensiasi. Oleh sebab itu biosistesis goniotalamin mungkin masih ditahap awal atau belum mencapai dari proses akhir yang harus dilalui. Namun begitu, biosistesis zat metabolit sekunder dapat dirangsang pembentukannya dengan penambahan zpt dan nutrisi atau senyawa kimia lainnya sebagai prekusor sehingga dapat menginduksi sel-sel tersebut menuju arah diferansiasi sel.

\section{SIMPULAN}

1. Hasil kultur kalus $G$. tapis pada media kombinasi $D_{5} B_{1}\left(5,0 \mathrm{mg} \mathrm{l}^{-1} 2,4-D+1 \mathrm{mg}\right.$ $\left.\mathrm{I}^{-1} \mathrm{BAP}\right)$ adalah media perlakuan yang terbaik berbanding dengan media perlakuan lainnya terhadap parameter waktu muncul kalus yaitu 28,33 hari, persentase pembentukan kalus yaitu $100 \%$, tekstur kalus yang bagus yaitu remah, mudah dipisahkan dan berwarna kuning kehijauan.

2. Kultur suspensi sel menggunakan 5 media yang terbaik pada kultur kalus yaitu $D_{5} B_{0,5}, D_{5} B_{1}, D_{5} B_{2}, D_{10} B_{0,5}$ dan $D_{10} B_{1}$ menghasilkan pertumbuhan sel yang cepat, tidak lembek berair dan mudah dipisahkan.

3. Hasil Uji Kromatografi Lapis Tipis (KLT) yang sangat jelas dan bersih dan 
terdapat potensi kandungan zat goniotalamin terdapat pada media perlakuan $D_{5} B_{0,5}, D_{5} B_{1}, D_{5} B_{2}, D_{10} B_{0,5}$ dan $\mathrm{D}_{10} \mathrm{~B}_{1}$

4. Hasil Uji Kromatografi Cair Prestasi Tinggi (KCPT) kultur suspensi sel tanaman gajah beranak (Goniothalamin tapis) pada perlakuan $\mathrm{D}_{5} \mathrm{~B}_{1}$ (5,0 mg. $\mathrm{I}^{-1}$ 2,4-D+1 mg. $\mathrm{I}^{-1}$ BAP) adalah yang terbaik terhadap parameter pertumbuhan dan produksi goniotalamin yaitu $9,57 \mathrm{mg} / \mathrm{g}$.

\section{SARAN}

Penelitian lanjutan perlu dilakukan dengan menggunakan penambahan prekusor pada media kultur suspensi sel untuk menghasilkan bahan metabolit sekunder goniotalamin yang lebih tinggi berbanding pokok induk yang diinginkan.

\section{UCAPAN TERIMA KASIH}

Kami mengucapkan terima kasih kepada Lembaga Penelitian dan Pengabdian (LPPM) Universitas Riau yang telah membantu dana Hibah DIPA LPPM Universitas Riau 2021 dalam menyelesaikan penelitian ini.

\section{DAFTAR PUSTAKA}

Açikgöz, M. A., Kara, Ş. M., Aygün, A., Özcan, M. M., \& Bati Ay, E. (2019). Effects of methyl Jasmonate and salicylic acid on the production of camphor and Phenolic compounds in cell suspension culture of endemic Turkish yarrow (Achillea gypsicola) species. Turkish Journal of Agriculture and Forestry, 43(3), 351-359. https://doi.org/10.3906/tar-1809-54

Agarwal, M. (2015). Tissue culture of Momordica charantia L.: A review. Journal of Plant Sciences Journal of Plant Sciences. Special Issue: Medicinal Plants.
Azimahtol, H. L. P., Johnson, S., Devaraj, T., Manimaran, S., \& Laily, D. (1993). The potential of Goniothalamus extract as an antitumor agent. Proceedings of the Seventeenth Malaysia Biochemical Society Annual Meeting, 1-9.

Farhadi, N., Panahandeh, J., Azar, A. M., \& Salte, S. A. (2017). Effects of explant type, growth regulators, and light intensity on callus induction and plant regeneration in four ecotypes of Persian shallot (Allium hirtifolium). Scientia Horticulturae. https://doi.org/10.1016/j.scienta.201 6.11 .056

Fazeli-Nasab, B. (2018). The effect of explant, bap, and 2,4-D on callus induction of Trachyspermum ammi. Potravinarstvo Slovak Journal of Food Sciences. https://doi.org/10,5219/953

Jewers, K., Davis, J. B., Dougan, J., Manchanda, A. H., Blunden, G., Kyi, A., \& Wetchapinan, S. (1972). Goniothalamin and its distribution in four Goniothalamus species. Phytochemistry. https://doi.org/10.1016/S00319422(00)90168-7

Kashyap, S., Kapoor, N., \& Kale, R. D. (2016). Callus and Suspension Cell Culture of the Endangered Medicinal Plant Using Vermicompost Extract and Coelomic Fluid as Plant Tissue Culture Media. American Journal of Plant Sciences, 07(06), 899-906. https://doi.org/ 10.4236/ajps.2016.76085

Laily, D., Zuriati, Z., Mohd. Wahid, S., Abd. Hamid, A. H., \& Latifi, A. (1992). Sebatian terbitan stirilpiron dari pada Goniothalamus tapis Miqo (Annonaceae). Prosiding Seminar Kebangsaan Kumpulan Sebatian Semulajadi Ke 6, 121-126.

Mahadi, I. (2012). Induksi Kalus Kenerak (Goniothalamus umbrosus) 
Berdasarkan Jenis Eksplan Menggunakan Metode In Vitro. Jurnal Agroteknologi Tropika, 1(1), 18-22.

Mahadi, I., Syafi'i, W., \& Sari, Y. (2016). Callus Induction of Calamansi (Citrus microcarpa) Using 2,4-D and BAP Hormones by in vitro Methods. Jurnal IImu Pertanian Indonesia, 21(2), 8489.

https://doi.org/10.18343/jipi.21.2.84

Marisol Ochoa-Villarreal, Howat, S., Hong, S. M., Jang, M. O., Jin, Y. W., Lee, E. K., \& Loake, G. J. (2016). Plant cell culture strategies for the production of natural products. BMB Reports, 49(3), 149-158. https://doi.org/10.5483/BMBRep.201 6.49.3.264

Mat, S.K., \& Latiff, A. (2002). Tanaman Ubatan Malaysia. Universiti Kebangsaan Malaysia.

Mishra, M. R., Srivastava, R. K., \& Akhtar, N. (2019). Abiotic stresses of salinity and water to enhance alkaloids production in cell suspension culture of Catharanthus roseus. Global Journal of Bio-Science and Biotechnology.

Moharam, B. A., Jantan, I., Jalil, J., \& Ahmad, F. (2012). Inhibitory effect of compounds from Goniothalamus tapis Miq. and Goniothalamus overrides King on platelet-activating factor receptor binding. Phytotherapy Research.

https://doi.org/10.1002/ptr.3620

Robles-Martínez, M., Barba-De la Rosa, A. P., Guéraud, F., Negre-Salvayre, A., Rossignol, M., \& Santos-Díaz, M. D. S. (2016). Establishment of callus and cell suspensions of wild and domesticated Opuntia species: study on their potential as a source of metabolite production. Plant Cell, Tissue, and Organ Culture. https://doi.org/10.1007/s11240-0150886-0

Saunders, R. M. K. (2003). A synopsis of Goniothalamus species (Annonaceae) in Peninsular Malaysia, with a description of a new species. Botanical Journal of the Linnean Society. https://doi.org /10.1046/j.1095-8339.2003.00177.x

Shehzad, M. Aamir, Khan, M. A., Ali, A., Mohammad, S., Noureldeen, A., Darwish, H., Ali, A., Ahmad, A., Khan, T., \& Khan, R. S. (2021). Interactive effects of zinc oxide nanoparticles and different light regimes on growth and silymarin biosynthesis in callus cultures of Silybum marianum $\mathrm{L}$. Artificial Cells, Nanomedicine, and Biotechnology. https://doi.org/10.1080 /21691401.2021.1946069

Wiart, C. (2007). Goniothalamus species: A source of drugs for the treatment of cancers and bacterial infections? In Evidence-based Complementary and Alternative Medicine. https://doi.org/10. 1093/exam/nem009

Zainol, H., Ahmad, S., Syed, M., Mahmood, M., \& Mansor, H. (2019). Factors Affecting Cell Biomass and Flavonoid Production of Ficus deltoidea var. kunstleri in Cell Suspension Culture System. Scientific Repots 9 (1), 1-8. https://doi.org/10.1038/s41598-01946042-w 